\title{
Religiøs bestemmelse
}

Dansk Teologisk Tidsskrift bringer i dette nummer tre artikler, som alle på forskellig måde beskæftiger sig med rette religiøse bestemmelser.

I første artikel behandler Mogens Müller Justin som den første kendte bibelteolog. Müllers store arbejde med Septuaginta danner baggrunden for at vise Justins rolle som hovedfigur i 2. århundredes kristendom. Her bidrog Justin, der både var overbevist om Skriftens ufejlbarlighed og mente, at Skriften kun kan fortolkes af den, der har Ånden, i høj grad til at sikre Septuagintas status som kirkens bibel. I en tid, hvor andre, som $\mathrm{fx}_{\mathrm{x}}$ Markion, alene lagde vægt på Jesus-overleveringen, var Justin med til at fastholde kristendommens forbindelse til jødedømmen. Men han gjorde det uafhængigt af den jødiske tradition, hvilket netop den græske oversættelse gjorde muligt. Gennem læsningen af Apologierne og Dialogen giver Müller eksempler på Justins bibelbrug og viser blandt andet, hvordan Justin som den første bemærker forskellen mellem den hebraiske og den græske tekst.

I den næste artikel viser Jacob P.B. Mortensen, hvordan Fil 3,211 kan læses i lyset af det "radikalt" nye Paulusperspektiv, også kendt som "Paul Within Judaism". Hvis Paulus ikke bryder med jødedommen, men tværtimod skal forstås inden for den, så kan Fil 3,2's tale om "hundene" ikke være vendt mod jøderne. En "radikalt" ny Pauluslæsning må derfor lede efter andre tolkningsmuligheder. En kritisk efterprøvning af gængse fortolkninger, ifølge hvilke Paulus vender et hedninge-skældsord mod jøderne, viser, at de ikke kan bekræfte brugen af "hunde" som skældsord om hedninger i hverken Det Gamle Testamente, pseudepigrafer eller Dødehavsrullerne, og heller ikke hos hverken Filon eller Josefus. Brugen af "hundene" forstår man derfor bedst møntet på lokale problematiske grupper af hedninge i Filippi. En sådan tolkning understøtter det "radikalt" nye Paulusperspektivs bestemmelse af Paulus: at han aldrig opgav sin jødiske eksistens.

I den sidste artikel giver Rasmus H.C. Dreyer en historisk og indholdsmæssig indføring i den alternative og ofte oversete Confessio Tetrapolitana fra Augsburg 1530. Bekendelsen er forfattet af Martin Bucer og Wolfgang Capito og er udtryk for et forsøg på at bestemme en humanistisk præget mellemposition mellem Zwingli og Luther, karakteriseret ved biblicisme, et vagt nadversyn, samt en betoning af den kristnes nye liv og konsekenserne for det kristne societas. I artiklen sammenlignes Confessio Tetrapolitano med både Confessio Augustana og Zwinglis Fidei Ratio. Som afslutning gennemgår Dreyer de forskellige forbindelser, der var mellem Bucer og Danmark, af både personlig og teologisk karakter. 